\title{
Corrigendum: Comprehensive Analysis of the Expression and Prognosis for Laminin Genes in Ovarian Cancer
}

\author{
Bowen Diao and Ping Yang * \\ Department of Gynecology, First Affifiliated Hospital, School of Medicine, Shihezi University, Shihezi, China
}

Keywords: ovarian cancer, metastasis, laminins, cancer prognosis, bioinformatical analysis

\section{OPEN ACCESS}

Edited and reviewed by: Anna Sebestyén,

Semme/weis University, Hungary

*Correspondence:

Ping Yang

pingy2018@163.com

Received: 13 December 2021 Accepted: 11 January 2022 Published: 18 February 2022

Citation:

Diao B and Yang P (2022) Corrigendum: Comprehensive Analysis of the Expression and Prognosis for Laminin Genes in Ovarian Cancer. Pathol. Oncol. Res. 28:1610258. doi: 10.3389/pore.2022.1610258

\section{A Corrigendum on}

Comprehensive Analysis of the Expression and Prognosis for Laminin Genes in Ovarian Cancer by Diao, B., Yang, P. (2021). Pathol. Oncol. Res. 27:1609855. doi: 10.3389/pore.2021.1609855

There is an error in the Funding statement. The correct number for National Natural Science Foundation of China is " 82072893 ".

In the original article, there was an error. In the results section, the database name in the first paragraph was incorrect. A correction has been made to Results, Genetic Mutations in Laminins and Their Associations With Overall Survival and Disease-free Survival in Patients With Ovarian Cancer, paragraph one:

"We evaluated genetic alterations in laminins and their relationships with the OS and DFS of OC patients registered in the cBioPortal database".

The authors apologize for this error and state that this does not change the scientific conclusions of the article in any way. The original article has been updated.

Copyright $\odot 2022$ Diao and Yang. This is an open-access article distributed under the terms of the Creative Commons Attribution License (CC BY). The use, distribution or reproduction in other forums is permitted, provided the original author(s) and the copyright owner(s) are credited and that the original publication in this journal is cited, in accordance with accepted academic practice. No use, distribution or reproduction is permitted which does not comply with these terms. 